\title{
Policy assessment on displacement of 1.6 liters and below passenger car purchase tax in 2015
}

\author{
R.GENG ${ }^{1}$,Z.Y. CHEN ${ }^{2}$ \\ ${ }^{1}$ Reseach Institute of Highway Ministry of Transport, Beijing, china \\ ${ }^{2}$ Reseach Institute of Highway Ministry of Transport, Beijing, china
}

KEYWORD: Transportation engineering; Transport economics; Policy evaluation.

ABSTRACT: In 2015, the purchase tax on passenger vehicles with engine displacement of 1.6 liters or less was reduced. The upgrade of auto industry structure has great effects on energy saving and emission reduction. The policy has 6 aspects influences of highway planning and construction and the influence on the pulling effect of the national economy tax the income effect, car purchase.

\section{POLICY BACKGROUND}

September 2015, to promote the development of new energy and small cars, eliminated emission vehicles exceed the standard, will help ease the energy and environmental pressure, promote the automobile industry structure optimization and upgrading of consumption, foster new economic growth point, the State Council executive meeting decided that from October 1, 2015 to December 31,2016 , for the purchase and below 1.6 liters of displacement passenger vehicles to implement halved purchase tax (hereinafter referred to as the "15 policy"). The reduction of the policy period is approaching, the effect of the implementation of the policy? What are the problems? Should it be extended or adjusted?

\section{ANALYSIS OF THE IMPACT OF 1.6 LITERS AND BELOW DISPLACEMENT PASSENGER CAR SALES}

Quarter before the introduction of the policy before 2015 three, the automobile production and sales continue to fall, "15" policy implementation up to a certain effect. The fourth quarter of 2015, 1.6 liter and below passenger car sales year-on-year net increase of about 910 thousand vehicles, accounting for 1.6 liter and below passenger car total sales of $66.5 \%$, making 2015 car sales reached 24 million 598 thousand units, representing an increase of 4.7\%. Among them, 20151.6 liters and the following passenger car sales of 14 million 509 thousand, year-on-year growth of $10.4 \%$, higher than the overall growth rate of the car, the proportion of car sales accounted for 59\%; while the commercial vehicle sales of 3 million 451 thousand vehicles, down 9\%, a larger decline. In 2016 1-6 month, car sales 12 million 830 thousand, an increase of $8.1 \%$, an increase over the same period last year increased by 6.7 percentage points, of which 1.6 liters and the following passenger car sales in the first half of 7 million 966 thousand, an increase of $14.5 \%$, accounting for passenger car sales accounted for $72.2 \%$.

But on the other hand, compared to the 2009 implementation of the car purchase tax halved (hereinafter referred to as the 09 Policy), a total of 1.6 liters and a small passenger car sales of small cars, an increase of 71.28\%. In December 20151.6 liter and below passenger car sales of 1 million 731 thousand, an increase of $26.9 \%$ compared to 2009 and 2010, the explosive growth of the larger gap, to a certain extent also reflects the vehicle purchase tax reduction policy stimulus syndrome continues to weaken.

As can be seen, the 15 policy has a certain effect on car sales. On the longitudinal comparison of the 09 policy and the "15 policy" on the effectiveness of car sales pull, it can be judged that the tax policy on car sales is the rapid decline in the role of the stimulus. 


\section{ANALYSIS ON THE INFLUENCE OF UPGRADING OF AUTOMOBILE INDUSTRY STRUCTURE}

Although the automotive industry has not been included in the production capacity of the key industries, but can be seen from the vehicle capacity utilization, structural overcapacity problem has emerged. 2015, accounting for $98 \%$ of China's automobile production of the 37 major auto companies to form a vehicle production capacity of 31 million 220 thousand. Where the passenger capacity of 25 million 750 thousand units, capacity utilization rate of $81 \%$; at present, China's automobile industry is facing the throes of transition, the shift of growth and had high growth of digestion period, the automobile market volatility will promote industrial transformation and upgrading, integration, can take the opportunity to eliminate a number of backward enterprises and backward production capacity through the vehicle. The implementation of mergers and acquisitions and other initiatives to achieve Chinese automobile industry from more than fine is not strong to less and fine and strong direction.

However, in the first half of this year, Chinese car city just passable, China's automobile production and sales 12 million 892 thousand and 200 and 12 million 829 thousand and 800 vehicles, an increase of $6.47 \%$ and $8.14 \%$, respectively over the same period last year increased by 3.83 percentage points and 6.71 percentage points. Which passenger car sales 11 million 99 thousand and 400 and 11 million 42 thousand and 300, an increase of 7.32\% and 9.23\%. China Automobile Association released in August 3rd "China auto dealer inventory warning index survey VIA (Vehicle Inventory Alert Index) also showed that the automobile circulation pressure pile up in excess of requirement has slowed down, July 2016 inventory warning index was $49.5 \%$, down 10.2 percentage points higher than last month, inventory warning index fell to below the warning line.

While the market is showing significant overcapacity, while the policy induced by showing shortterm sales strong, some consumers will induce this plan after a few years ahead of schedule to Car Buying tax preferential purchase period caused the increase in sales. This rapid growth of short-term trend if the misleading car manufacturers to further increase the 1.6 liter and below the small car production capacity and output in the short term, may enjoy the dividend policy at the same time, to bring long-term bear market overdraft, including overcapacity and various problems concealed negative pressure factor.

In the long run, the stage of tax cuts will not solve the fundamental problems of China's automobile industry, the rapid growth of sales in previous years also left too many problems and sequelae, if the long-term tax cuts, subsidies and other policies to stimulate not consistent with the direction of industrial development capacity consumption, for the long-term development of the automobile industry is to poison.

\section{THE IMPACT OF TAX ON VEHICLE PURCHASES}

from the actual statistical data, car purchase tax revenue showed a significant downward trend. As can be seen from the data over the years, with the car production and sales increased significantly, in general, the car purchase tax revenue also showed a rapid growth trend. From 2001 to 2014 this 14 years, car purchase tax revenue increased by more than 10 times, from $\$ 25$ billion 520 million to $\$ 288$ billion 470 million. But in 2015, the first half of 2016, car sales in the overall growth of the case, the vehicle purchase tax income but there was a substantial decline, fell $3.2 \%, 12.7 \%$, this is mainly for the following reasons: one is the implementation of the 1.6 liters and the following displacement passenger car vehicle purchase tax levied policy influence; two is due to car sales, although growth, but the growth rate is lower (and the vehicle purchase tax policy adjustment period of 2009 and 2010 compared to the larger gap); three is due to the central and local governments to support the introduction of a comprehensive new energy vehicle development policy (since September 1, 2014 to December 31, 2017, the new energy vehicles are exempt from vehicle purchase. Purchase tax), with the explosive growth of new energy vehicles in 2015, the annual sales of new energy 
vehicles 331 thousand vehicles, an increase of 340\%; 2016 Six months of new energy vehicle sales 170 thousand, an increase of $126.9 \%$ over the same period in 2015.

In addition, the bicycle tax, vehicle purchase tax levied with the level, structure and vehicle sales price level has a significant relationship, through the research, the historical data can be seen, in 2009,2015 , the first half of 2016 year-on-year fluctuations, fell significantly, mainly due to the vehicle purchase tax reduction policy tax levy the amount of bicycle.

Overall, from 2015 to 2016, car purchase tax revenue fell significantly year on year, the overall decline of $3.19 \%$ in 2016, the first 8 months of the year fell by $11.35 \%$. Especially since October 2015 after $\sim 12$ months just relief policy implementation, the vehicle purchase tax revenue declined faster, falling ratio increased from single digits to two digits, thus it can be seen that the vehicle purchase tax relief policy on income effect is more obvious.

"Tax cuts" to stimulate the growth of car sales generated car purchase tax, insufficient to make up for the reduction in the total amount of car purchase tax revenue.

"Tax cuts" can stimulate vehicle sales to a certain extent, but because of "car purchase tax" policy, so in theory, only when the stimulus vehicle sales doubled, to keep the vehicle purchase tax revenue is not affected. However, since the fourth quarter of 2015, the implementation of the tax cuts, the actual volume of up to 1.6 liters of displacement and the following passenger car is far less than doubled. For example, in December 20151.6 liters of displacement and the following passenger car sales were 1 million 731 thousand, an increase of $26.9 \%$ in $20161-6$ month sales rose by $14.5 \%$.

On the other hand, longitudinal comparison of tax cuts in 2009 and the 2015 tax cuts pull, policies on vehicle sales in 2009, 1.6 liters and small displacement car sales total 7 million 195 thousand and 500, an increase of 71.28\% in December 2015, 1.6 liter and below passenger car sales of 1 million 731 thousand, an increase of $26.9 \%$, compared with 2009 vehicle sales tax cuts policies lead to explosive growth, stimulus tax cuts for car sales is a rapid decay trend, completely up to "stimulate vehicle sales doubled" effect. Therefore, the purchase tax revenue has been adversely affected, will continue to show a downward trend.

As a result of the "tax cuts" transfer of the purchase of some large displacement vehicle sales demand, further to the car purchase tax revenue adversely affected.

The relief policy is limited to 1.6 liters and the following displacement of the vehicle, therefore, will attract part of the original plan to buy 1.6 liters or more cars to consumers, affected by tax incentives to purchase 1.6 liters and the following displacement of the vehicle, called the "displacement transfer amount". 20151.6 liters and below passenger car sales of 14 million 509 thousand, accounting for the proportion of passenger car sales in the first half of 2016, the first half of the year 1.6 liters and below passenger car sales in the first half of the year, accounting for the proportion of passenger car sales of $72.2 \%$ for the year of $68.6 \%$ in the first half of. It can be seen that 1.6 liters and below passenger cars accounted for the proportion of passenger car sales increased, indicating that more than 1.6 liters of large displacement passenger cars accounted for the relative reduction.

From the taxable price of the vehicle, 1.6 liters and below the taxable price of passenger cars in general will be less than the taxable price of more than 1.6 liters of passenger cars, so the car purchase tax is also less than 1.6 liters or more passenger cars.

In 2009 the implementation of the policy of tax cuts due to increase the displacement of 1.6 and below cheap car sales accounted for, had a dramatic effect on the average single tax, dropped to 8 thousand and 500 yuan from 10 thousand and 600 yuan, again in 2016 the implementation of tax policy, had the same effect, the average single tax dropped to 9 thousand and 900 yuan from 11 thousand and 400 yuan. Thus, due to the tax policy, the rise in the proportion of low-priced car sales, making the average bicycle tax decline, further to the car purchase tax revenue has a negative impact.

\section{IMPACT ON HIGHWAY PLANNING AND CONSTRUCTION}

In mid 80s, the State Council decided to levy a surcharge (tax), in order to reverse the state fiscal investment in transport infrastructure in the serious shortage of funds, the implementation of the traffic 
policy provides strong support for the rapid development of the transportation industry, and together with the toll road policy has become the cornerstone of traffic development financing policy. In more than thirty years of transportation construction, car purchase tax is the most important and most stable source of funds for the central investment in transportation infrastructure, in the case of insufficient financial resources, effectively play the role of capital oriented.

As can be seen from the data over the years, with the car production and sales increased significantly, in general, the car purchase tax revenue also showed a rapid growth trend. From 1985 the introduction of vehicle purchase surcharge (tax) to 2014 this 30 years, the vehicle purchase tax revenue increased by more than 166 times, increased from 1 billion 720 million yuan to 288 billion 470 million yuan, has played a huge role in the development of national transportation, and laid a solid foundation for China's economic leap forward development.

Due to the "weakened 15 policy" to 1.6 liters and the following vehicle purchase tax reduction and bicycle sales stimulation effect, since the beginning of October 1, 2015 and below 1.6 liters of displacement passenger car vehicle purchase tax levied by the policy, the 2015 car purchase tax income for the first time a year down the situation, in this year's 1-6 month, car purchase tax revenue yearon-year decline further expanded, reached 12.7\%, according to forecasts, 2016 vehicle purchase tax reduction of 67 billion 900 million yuan of funds than expected, will seriously affect the vehicle purchase tax as traffic arrangements and the use of special funds. If the "15 policy" in the continued implementation of "13th Five-Year" during the year, the vehicle purchase tax will be reduced by about 70 billion yuan.

The transportation department according to the "13th Five-Year" period of national transportation infrastructure facilities planning calculations of the vehicle purchase tax with the size of about 300 billion yuan / year, mainly for the national highway construction, national and provincial trunk highway construction and rural reconstruction. If the "15 policy" in the continued implementation of "13th Five-Year" during the year will affect more than $20 \%$ of the national planning scale of transportation infrastructure construction, will have a negative impact on the implementation of the national transport planning target of "13th Five-Year".

The vehicle purchase tax supported national highway, national and provincial trunk and rural road infrastructure, is the strategic infrastructure of national economic and social development, is an important starting point to promote the national "steady growth", is an important measure to promote the national "precise poverty treatment, which may be because the car purchase tax relief the policy effect of highway traffic infrastructure construction to achieve the objectives, which have been linked to influence.

\section{THE EFFECT OF PULLING THE NATIONAL ECONOMY}

You can pull the benefit of highway construction investment to the national economy is divided into direct and indirect benefits and economic benefit, which accounted for, direct benefit refers to the net contribution of highway investment in highway construction of highway construction industry output and employment do; indirect benefits in highway construction activities, increase the value of the direct consumption of cement, steel, asphalt, wood and other items, these items, such as power consumption of ore intermediate goods to create economic benefits due to the induction; intermediate input sector employment income resulting from the increase of the final demand to increase the consumption multiplier benefits. According to the research results of input-output model, the total contribution rate of highway construction investment to the national economy is 3.3-3.6, that is to say, every investment of 1 yuan is used for highway construction, which can produce the national economy pulling effect of 3.3-3.6 yuan.

Similarly, the automobile industry is the long tail of the upstream industry, related industries have black metal smelting and rolling processing industry, chemical materials and chemical products manufacturing, electricity and heat production and supply industry, non-ferrous metal smelting and rolling processing industry, petroleum and nuclear fuel processing and so on, downstream related indus- 
tries including service industry, transportation and warehousing, wholesale and retail finance and insurance industry and accommodation and catering industry etc.. According to the State Council Development Research Center, the survey shows that the domestic automobile manufacturing industry value of 1 yuan each, can effectively promote the upstream and downstream related industries added value of 2.64 yuan.

From the above research results, we can see that under the same investment in highway construction and automobile industry, the highway construction is more important than the automobile industry to the national economy.

On the other hand, 1.6 liters and the following tax relief policy is the main solution of 1.6 liters and the following displacement car "to stock", rather than pulling its manufacturing, manufacturing and inhibited the 1.6 liters or more cars, more reduced automobile manufacturing to the national economy pull effect.

\section{POLICY SUGGESTION}

From the perspective of promoting the transformation and upgrading of the automotive industry, car purchase tax reduction policy should expire after the exit. The introduction of the automotive industry support policies are necessary, but we must highlight the relevance and stability. From a shortterm perspective, the purchase tax reduction policy on the automotive market is the most important value to stimulate sales. In order to stimulate the automobile consumption subsidy policy for shortterm purposes, is to the future consumption overdraft market price, to improve the enterprises especially the independent brand development capabilities, brand image and service level and other aspects of the role is limited, but easy to condone domestic car enterprises R \& D and production business on inertia.

From the perspective of the economic downturn is conducive to easing the pressure analysis, car purchase tax reduction policy should expire after the exit. Because the car purchase tax as the most important transportation development of the central special funds, in the promotion of the national transportation infrastructure investment and development play a huge role in stimulating and guiding. The transportation industry is the basic industry of the national economy, will have a multiplier effect on the construction of transportation infrastructure investment, expand the business sector in the national economic output and improve the level of profit, and promote the growth of consumption, resulting in economic growth. Therefore, the purchase tax reduction policy to a certain extent, affected the development of the transportation industry, which also affected the growth of the national economy.

To sum up, does not support the continued vehicle purchase tax reduction policy, suggested that the relevant departments should timely exit in the policy expires.

\section{reference}

[1]ZHOUjianguo. The logic, Dilemma and outlet of independent third party in policy evaluation . Jianghaiacademic Journal, 2009 (6)

[2]LVwei. The assessment and suggestion Chinese environmental protection policy. Shanxi Architecture 2012 (31)

WANGhaiyong, RANxiaoxi. Environmental protection and tax and fee policy. Journal of Henan Normal University,2006 (1)

[3]DOUwei, YANGyaqi. "Plastic limit" effect and Countermeasure Study on the implementation of the policy, China Environmental Protection Industry, 2010 (2)

[4]HEzhenghua,HOUshian. The macro analysis of China's structural tax policy effect. China tax, 2009 (9)

[5]CHENzhenming. Public policy analysis.Beijing: Renmin University of China press, 2003 
[6]GAOxingwu. Public policy evaluation system and process. Administrative management in China, 2008 (2)

[7]William Dunn, Introduction to public policy analysis, Beijing: Renmin University of China press, 2002

[8]LIANGhenian, Policy planning and evaluation. Beijing: Renmin University of China press,2009

[9]ZHAOxiaoli. Research on theory and method of innovation policy evaluation based on the logic framework of public policy evaluation. Science Research, 2014 (2)

[10]YANGchenghu. Public policy evaluation: Theory and method. Beijing: Social Science Press Chinese, 2006

[11](US) Egon G, goube etc. The fourth generation evaluation. Beijing: Renmin University of China press, 2008 